\title{
PERSONNEL FUNCTION AUDIT AS A QUALITY-PROMOTING TOOL IN HUMAN RESOURCE MANAGEMENT IN A LOCAL GOVERNMENT UNIT
}

doi: 10.2478/cqpi-2019-0025

Date of submission of the article to the Editor: 11/04/2019

Date of acceptance of the article by the Editor: 28/05/2019

Agata Przewoźna-Krzemińska- orcid id: 0000-0001-8727-0852

Częstochowa University of Technology, Poland

\begin{abstract}
With progressive globalization, changes in the business environment and growing competition, modern companies have been facing challenges and the need for anticipating changes and new threats in the market. Consequently, enterprises operating in a situation of uncertainty are forced to analyze everything that is happening both outside and inside the organization in detail. Managers should pay attention to the atmosphere in the enterprise, communication, cooperation, motivation, etc. The ability of the organization to utilize and manage human resources rationally in order to improve the effectiveness and quality of work is critical. New challenges in the organization, diversity of activities, implementation of new or appropriate rebuilding of old methods (functions) can be ensured by their audit, especially HR audit, whose task is to examine all issues related to the implementation of the personnel function. The aim of this paper is to discuss an audit of personnel functions conducted in a local government unit and to present guidelines, effects and results aimed at improving work and its quality. The paper has a theoretical and empirical character.
\end{abstract}

Keywords: human resource management, quality, audit, audit of personnel function

\section{Introduction}

Growing competition on the market makes it more and more difficult to increase company values and employee satisfaction and commitment. Entrepreneurs and managers are looking for a variety of ways and methods to stay in the market, be more competitive, be more effective and constantly improve their quality. To this end, they invest in modern technologies and the latest IT solutions by implementing modern software for HR departments, e.g. for employee appraisal. The HR area faces new challenges, constant changes in the legislation, mainly in the area of the labour law (e.g. amendments to the Labour Code, General Data Protection Regulation - RODO) and such changes disturb the status quo in the organization. Sometimes entrepreneurs plan to close a business or declare bankruptcy because they do not know how to save a company. In many cases, an audit may be the last resort, which is very often a personnel audit, which indicates the areas to be repaired in the company, and areas that the entrepreneur would never plan to change or update. Human capital 
management should be regularly improved, and one of such instruments of improvement in this area is a personnel audit, which allows for checking whether the institution efficiently manages personnel. For many years, the so-called HR audit has been used in Western European and American countries, termed in Poland the HR function audit. More and more often the term personal audit is used in the literature of the organization and management as it includes all the elements of the audit of the personal function and HR audit. In most organizations, audit is usually an element of their personnel strategy, i.e. a certain declaration of managers to treat employees properly and to perform their personal function properly" (Przewoźna-Krzemińska, 2017).

The aim of this paper is to discuss an audit of personnel function conducted in a local government unit and to present guidelines, effects and results aimed at improving work and its quality. The ability to use and manage human resources rationally in order to increase the effectiveness and quality of work is extremely important for the organization. New challenges in the organization, diversity of activities, implementation of new or appropriate remodeling of old methods (functions) can be ensured by their audit, especially HR audit, with its task being to examine all issues related to the implementation of the personnel function. The paper will attempt to answer the question "Why are managers, entrepreneurs and employers afraid of audits"? Is this because the very word audit (external, internal, personnel, etc.) has a pejorative meaning, is associated negatively and is usually related to control in the company. The concepts of audit and control in a company are diametrically opposed. Lack of understanding of what audit is by managers, lack of knowledge of its role and tasks are common, and even auditors often narrow down the role of the audit and conduct it improperly. This is due to inadequate training and, as a consequence, poor preparation of the people conducting the audits. Learning the methodology of conducting the audit process is not enough, but the most important thing is to be aware of the need to carry out this process and, above all, to feel its essence. The difference between audit and control is shown in Table 1.

Table 1.

Difference between audit and control

\begin{tabular}{|l|l|}
\hline Audit (Latin. Auditio - listening, learning) & \multicolumn{1}{|c|}{$\begin{array}{c}\text { Control (franc.Controls - verification, } \\
\text { supervision, examination) }\end{array}$} \\
\hline $\begin{array}{l}\text { independent and made by choice; carried } \\
\text { out based on a general standard of } \\
\text { requirements }\end{array}$ & $\begin{array}{l}\text { limited by the scope of the authorization and } \\
\text { typically imposed }\end{array}$ \\
\hline oriented towards improvement & carried out based on various regulations \\
\hline $\begin{array}{l}\text { determination whether there have been any } \\
\text { deviations from the desired state }\end{array}$ & check (checking activities) \\
\hline searching for and confirmation of conformity & oriented at nonconformities \\
\hline $\begin{array}{l}\text { emphasizes the causes and symptoms of } \\
\text { phenomena. }\end{array}$ & finding nonconformity \\
\hline oriented towards improved activity & $\begin{array}{l}\text { oriented towards detecting nonconformities } \\
\text { and their perpetrators }\end{array}$ \\
\hline
\end{tabular}

Source: author's own study based on literature analysis (Bednarek 2014). 


\section{Terminological determinants of the audit concept}

The term and procedure of the auditing were created as early as in the 19th century. Audit was mainly external in nature, it was an activity of independent experts who examined financial problems in the company (Mytlewski, 2011). At the beginning of the 20th century, companies began to employ internal company auditors who examined accounting procedures, regulations and transparency of internal control. Therefore, the characteristics, tasks and objectives of an audit indicate that it cannot be identified with control. The phenomenon of audit is closely related to the quality standards and quality management system as a process of testing compliance with the standard. Since the beginning of the 1990s in Poland, companies that decided to have a certified quality management system were obliged to conduct internal audits (first party) and external audits (third party). "The audit procedure is a very detailed and complicated quality assurance procedure in qualitative" (Akkerman, 2008). The problem with the accurate definition of the concept of audit and the proper fit and location within the management of the organization still arouses discussion among theoreticians dealing with this process. The most popular definition of audit was defined by researchers from the Institute of Internal Auditors (IIA). According to this definition, 'internal audit is an independent, objective, assurance and advisory activity designed to bring value added to the organization and improve its functioning. Internal audit supports the organization in achieving its objectives through regular and consistent activities aimed at assessing and improving the effectiveness of risk management, the control system and the organization's management processes"(Czerwiński, 2015). The concept of audit was also defined in the Polish legal system in the Act on Public Finance of 27 August 2009. Article 272 states that internal audit 'is an independent and objective activity aimed to assist the minister in charge of a department or a head of unit in achieving the objectives and tasks through the regular evaluation of management control and advisory activities"(Public Finance Act, Paragraph 1). The audit defined in this way by the legislation concerns mainly the management control in the government administration department or its unit. This paper presents the course of the audit of the personal function while the definition of this audit also raises some problems and controversies. The following terms appear interchangeably in the literature: operational audit, organizational audit, personnel audit, HR audit, and audit of personnel function. An attempt to distinguish between the above mentioned terms is presented in Table 2.

Table 2.

Concepts of audit

\begin{tabular}{|c|c|c|c|}
\hline Personnel audit & $\begin{array}{c}\text { Organizational } \\
\text { audit }\end{array}$ & HR audit & $\begin{array}{c}\text { Personnel function } \\
\text { audit }\end{array}$ \\
\hline \begin{tabular}{|l|} 
adiagnostic tool used \\
to analyse the \\
personnel status in \\
the company; \\
itsactions concern \\
employees: human \\
resources in the \\
organization and the \\
way they are \\
managed.
\end{tabular} & $\begin{array}{l}\text { tools, methods used } \\
\text { to improve the } \\
\text { effectiveness of } \\
\text { activities by } \\
\text { improving } \\
\text { communication, } \\
\text { improving the quality } \\
\text { of company } \\
\text { management; during } \\
\text { audit activities, the } \\
\text { level of identification }\end{array}$ & $\begin{array}{l}\text { a tool analogous to a } \\
\text { personnel function } \\
\text { audit (in Poland used } \\
\text { interchangeably, } \\
\text { often as a synonym), } \\
\text { however, it is a } \\
\text { broader process of } \\
\text { the analysis of } \\
\text { personnel areas } \\
\text { since it covers } \\
\text { additional areas, }\end{array}$ & $\begin{array}{l}\text { a tool covering the } \\
\text { assessment of example } \\
\text { areas: recruitment and } \\
\text { selection procedures, } \\
\text { adaptation procedures } \\
\text { for new employees, HR } \\
\text { and payroll } \\
\text { departments' work } \\
\text { organization, internal } \\
\text { communication, } \\
\text { development }\end{array}$ \\
\hline
\end{tabular}




\begin{tabular}{|l|l|l|l|}
\hline & $\begin{array}{l}\text { of employees with } \\
\text { the company is } \\
\text { examined. }\end{array}$ & $\begin{array}{l}\text { such as work-life } \\
\text { balance, } \\
\text { communication, } \\
\text { employee adaptation, } \\
\text { occupational safety } \\
\text { and health etc. }\end{array}$ & $\begin{array}{l}\text { programmes, employee } \\
\text { performance appraisal } \\
\text { procedures, etc. }\end{array}$ \\
\hline
\end{tabular}

Source: Author's own study based on literature analysis (Marciniak, 2010 and Pocztowski, 2008).

Analysis of the distinction between the concepts contained in the table leads to the conclusion that they concern the same issues, i.e. employees employed in the organization and undergoing different stages of the human resources process in a given organizational climate and personnel policy. The theoreticians of organization and management have presented this process in a similar way. For example, Pocztowski emphasized that "an audit is an independent and methodical examination of the compliance of human resources and the HRM system with the relevant standards adopted before. In its essence, audit is aimed at improving strategies, processes and methods of HRM' (Pocztowski, 2003). Furthermore, Padzik argued that "the subject of diagnosis of HR audit is the personnel employed in the organization and the way these people are managed" (Padzik, 2002). The audit personal (HR audit, personnel function audit) represents a monitoring and advisory study, which aims to improve the current manner of human resources management in accordance with existing, established standards or reference standards. The audit procedure is presented in Table 3.

Table 3.

The audit procedure-stages.

\begin{tabular}{|c|c|}
\hline audit procedures & stages \\
\hline 1/ orientation to the audit procedure & $\begin{array}{l}\text { the auditee and the auditor negotiate and } \\
\text { agree upon goals, roles, and rules of the } \\
\text { audit }\end{array}$ \\
\hline 2/ orientation to the study & $\begin{array}{l}\text { the auditee explains the audit trail in order } \\
\text { for the auditor to become familiar with the } \\
\text { study }\end{array}$ \\
\hline 3 / determining the auditability of the study & $\begin{array}{l}\text { the auditor determines the completeness, } \\
\text { comprehensibility, and utility of the audit trail }\end{array}$ \\
\hline 4/ negotiating the contract & $\begin{array}{l}\text { the auditee and auditor establish a time line, } \\
\text { the format of the outcomes, and the criteria } \\
\text { for renegotiation }\end{array}$ \\
\hline $5 /$ the actual assessment & $\begin{array}{l}\text { the auditor assesses the research process in } \\
\text { terms of the criteria visibility, } \\
\text { comprehensibility, and acceptability }\end{array}$ \\
\hline $6 /$ renegotiation & $\begin{array}{l}\text { the auditor presents the findings and } \\
\text { discusses discrepancies with the auditee; } \\
\text { the auditee and auditor determine what } \\
\text { actions will follow (for instance - redesigning } \\
\text { the research process, adjusting the auditor } \\
\text { report, or modifying the agreement). }\end{array}$ \\
\hline $7 /$ the final auditor report & $\begin{array}{l}\text { the auditor writing the final auditor report on } \\
\text { the quality of the study }\end{array}$ \\
\hline
\end{tabular}

Source: https://journals.sagepub.com/doi/full/10.1177/1609406918763214

"The audit procedure in itself indeed is a complex procedure, when it is followed through and reported on in a transparent way, it helps judge the value of the audit as a method 
of quality assurance"(Akkerman et al., 2008). "The audit procedure requires time and effort of both the auditee and the auditor, most researchers recognize its value in terms of increasing and establishing quality in qualitative research"(de Kleijn, Van Leeuwen, 2018). The audit procedure is meant to increase the validity of a qualitative study, but this can only be the case when it is clear how the audit procedure was performed. (Morse et al., 2002; Poortman \& Schildkamp, 2012).

\section{Personnel audit in a local government unit}

The literature survey on personnel audit was extended by empirical research. For the purposes of this paper, only a part of the research conducted in November 2018 in a local government unit in Częstochowa, Poland, was presented. The research tool was the analysis of documents and survey questionnaires which were addressed to the officials of the examined department in the public unit.

Periodic Employee Appraisal System is a deliberately selected and organized set of elements of the system and relations with other solutions in the personnel area, designed to improve the effectiveness of human resources management in the context of the achievement of the set goals and mission of the organization (Szałkowski, 2000). The paper presents the analysis of personnel audit concerning the performance of employee appraisal in a public institution. Employee appraisal is a formal method that allows for evaluation the work performed by the employee in the company. The appraisal is effective only if it is performed regularly (on an ongoing basis, at a specified time), in order for the appraisal process to meet expectations and make sense, two basic conditions must be met. The first condition concerns the evaluator, who must be competent to carry out this work. Evaluators should be professionals in their field, adequately prepared in both subject-related and formal terms, guided by the principle of objectivity in their appraisal. The second condition concerns the approach to appraisals and assumes that in larger companies there should be an appropriate appraisal system in place" (Czarnecka, 2008). Employee appraisal is one of the most important activities and stages of the human resources process and is central to human resources management in any organization, whether private or public. All employees are evaluated by their superiors, colleagues, subordinates and also perform selfevaluation. Appraisal serves informational, administrative and motivational purposes. Employee appraisals perform the following functions: evaluation (effectiveness of performance of the tasks in the organization), motivational (increasing motivation and commitment of employees), development (assessment of the level of competence and guidance for further activities regarding employee training), decision-making (the basis for personnel decisions related to a career, relegation or dismissal of an employee).

Each appraisal method should take into account the previously adopted objectives, principles, and evaluation criteria, which constitute an integrated reference system necessary for a rational choice of the method. The method or technique of appraisal is primarily determined by the information collected and the form in which the information collected is presented, and how the results of employee appraisal are compared and interpreted. "The appraisal represents an opinion that indicates the value of the employee in the organization. It is closely linked to all staff management functions and each staff member shall be subject to periodic or ongoing evaluation at all stages of his 
or her employment. HR appraisal is a highly controversial element of HR management and is also a very priority tool (Przewoźna-Krzemińska, 2010, 2015).

Theoreticians of organization and management have distinguished between the following stages of the appraisal process: 1/ organization and personnel strategy, 2/ identification of specific evaluation objectives, work analysis (criteria), $3 /$ creation of procedures, questionnaires, evaluation principles and updating of old procedures, 4/ evaluation of work performance, 5/ employee evaluation, 6/ discussion of evaluation results with the employee, $7 /$ formulation of employee development plans, $8 /$ decisions on remuneration (Koźmiński and Piotrowski, 2007).

The purpose of the personal audit discussed in this study and carried out in the selfgovernment unit was to collect the information on the correctness of employee appraisal. The study attempted to answer the following research questions:

- are the appraisal sheets (including the self-assessment section) updated, and, if so, how often are they updated?

- are descriptions of employee competences created on an ongoing basis in the department and are descriptions of employee competence profiles changed?

- how does the communication regarding employee appraisal look like?

- do the results of employee appraisals have an impact on professional career or, pay increase, relegations or dismissals.

The scope of the personnel audit was oriented towards the specific units (conducted in the Organizational Department and HR Department) and specific objects (its aim was to verify the correctness, regularity and legality of activities related to the creation of employee appraisals).

The methodology applied in order to conduct the audit is presented in Table 4.

Table 4.

Audit tools and activities

\begin{tabular}{|l|l|}
\hline \multicolumn{1}{|c|}{ Research tools used } & \multicolumn{1}{c|}{ Activity } \\
\hline - review tests & $\begin{array}{l}\text { verification and identification of the current principles of the } \\
\text { appraisal system under examination (its subsystems) and } \\
\text { confirmation (or not) of the control through the use of the } \\
\text { following techniques: } \\
\text { - analysis of official documents, } \\
\text { - explanatory interviews with staffs on appraisals, based on } \\
\text { internal control questionnaires. }\end{array}$ \\
\hline - compliance tests & $\begin{array}{l}\text { conducting the analysis of the procedures examined and } \\
\text { identified in order to assess their degree, level and scope } \\
\text { of application by using the following techniques: } \\
\text { - comparison of the defined and recorded data sets with } \\
\text { the criteria established by the auditors; } \\
\text { - checking the reliability and truthfulness of the information } \\
\text { and comparing it with external information. }\end{array}$ \\
\hline - actual performance tests & $\begin{array}{l}\text { - using observations (superiors, co-workers, subordinate } \\
\text { employees) concerning the entire year's work of an } \\
\text { employee (performance of tasks, attitude to work, quality of } \\
\text { work), taking into account his or her achievements, } \\
\text { progress, work results, mistakes and penalties. }\end{array}$ \\
\hline
\end{tabular}

Source: author's own study based on the Manual of Internal Audit in Public Administration and materials obtained from the institution. 
In the examined office, after carrying out tests (in accordance with the relevant Ordinance of the President of the City on establishing the precise procedure for carrying out periodic qualification appraisal of employees of the office), review, compliance and, above all, tests of real performance, the auditors found that:

- the purpose of periodic evaluations conducted in the office is to obtain information on the direction of the employee's development, training, courses, new qualifications and competencies and to determine the usefulness of the employee at a specific position; - the appraisal used in the examined unit is point-descriptive in nature, performed by its direct superiors during the appraisal interview. On the other hand, employees who in the period studied were transferred to another department, and more than 3 months had already passed since that moment, were assessed in the new department. Every employee is obliged to sign the appraisal form personally after reviewing the results of the employee appraisal and has the right to appeal within 7 days of signing the evaluation form. The appeal is analyzed within 14 days of the deadline (previously set by the relevant ordinance) for the submission of employee appraisal sheets to the relevant HR department. It is worth noting that the appraisal issued in the appeal mode is final and the appraisal sheet is included in the employee's personal file. The unit uses the following grading scale: distinguishing, very good, good, appropriate and negative. As a result of the audit of employee appraisals in the audited local government unit, the auditors stated that 225 officials were subject to appraisal: 81 received a distinguishing grade, 71 a very good grade, 48 a good grade, 9 people received an appropriate grade, while 6 employees were not subject to employee evaluations due to long-term absence from work (parental leave, rehabilitation leave, etc.). The auditors compared (with the actual situation) the conclusions of the superiors contained in the documents with the staff appraisal sheets in terms of the aspects concerning employee promotion and the resulting increase in salaries. Based on the analysis of the results of the audit findings, it was found that, using employee appraisals, superiors requested a higher position for 16 officials, but only 10 were promoted, whereas 45 employees received a salary increase.

\section{Conclusions from the personnel audit concerning employee appraisal}

The key objective of the audit of employee appraisals in the budgetary unit was to prepare substantive premises for changing the positions, promotion or relegation of officials. The audit allowed the managers to:

- verify whether employees work in appropriate workstations, in accordance with their competences;

- $\quad$ plan their career paths (promotions to higher positions);

- plan staff training (who should be trained and which training should be used according to the training needs), while at the same time receiving accurate information about the staff's potential;

- they could also prioritise jobs (from the most important to the most redundant jobs that can have an impact on the reduction of employment).

The numerical data obtained after the employee appraisals are worrying, namely too few persons promoted in relation to the distinguishing and very good grades, and a small number of persons who received higher remuneration. This is probably due to the specificity of the budgetary organization and the legal conditions that regulate salaries 
in budgetary units. Based on the results of the employee appraisal audit, the public entity can take a number of strategic decisions, corrective and development actions in relation to the department employees and can also update the appraisal sheets, introduce new procedures (regulations) concerning the employee appraisal system, because the current ones are too liberal. The results of the audit may lead to better motivation and commitment, which may be an excellent tool for improving the quality of work. It is important to know the importance of the audit and the benefits it can bring not only to the employer but also to all members of the organization. Innovative and modern organizations use the latest trends in human resource management. One of the elements of HR improvement is to conduct personnel audits, which are becoming a more and more appreciated tool to improve the quality of the organization. "Providing answers to the question whether the organization effectively manages human resources, personnel audit becomes an effective and helpful management tool" (Majowska, 2015).

\section{Reference}

Akkerman, S., Admiraal, W., Brekelmans, M., Oost, H. 2008. Auditing quality of research in social sciences. Quality and Quantity, 42.

Bednarek, P., 2014. Performance Measurement in the Internal Audit Departments in Poland-the state of the Art Prospects for Development. Wydawnictwo Uniwersytetu WarmińskoMazurskiego, Olsztyn.

Czarnecka, A., 2008. Oceny pracownicze. Wybrane problemy zarządzania kapitałem ludzkim. Wydawnictwo Politechniki Częstochowskiej, Częstochowa.

Czerwiński, K., 2005. Audyt wewnętrzny. InfoAudit, Warszawa.

Renske de Kleijn, Anouschka Van Leeuwen, 2018, Reflections and Review on the Audit Procedure: Guidelines for More Transparency, International Journal of Qualitative Methods, vol. $17,1$.

Koźmiński, A.K., Piotrowski, W. 2007.Zarządzanie. Teoria i praktyka. Wydawnictwo Naukowe PWN. Warszawa.

Majowska, M., 2015. Audyt personalny jako narzędzie usprawniające proces zarządzania zespołem pracowniczym. Zeszyty Naukowe nr 230. Uniwersytet Ekonomiczny w Katowicach. Manual of Internal Audit in Public Administration https://www.amazon.ca/Public-GovernanceReviews-Internal-Administration/dp/9264309683.

Marciniak, M., 2010. Audyt funkcji personalnej w przedsiębiorstwie. Wolter Kluwer Polska, Warszawa.

Morse, J. M., Barrett, M., Mayan, M., Olson, K., Spiers, J. 2002. Verification strategies for establishing reliability and validity in qualitative research. International Journal of Qualitative Methods, 1.

Mytlewski, A., 2011. Audyt wewnętrzny w reorientacji ogniw łańcuchów dostaw. Czasopismo Logistyka $\mathrm{nr} 3$.

Padzik, K., 2002. Leksykon HRM. Podstawowe pojęcia z dziedziny zarządzania zasobami ludzkimi. C.H.B., Warszawa.

Pocztowski, A., 2003. Zarządzanie zasobami ludzkimi. PWE. Warszawa.

Pocztowski, A., 2008. Teoretyczne i metodyczne aspekty audytu personalnego. Zeszyty Naukowe nr 773. Uniwersytet Ekonomiczny w Krakowie, 5-17.

Poortman, C. L., Schildkamp, K., 2012. Alternative quality standards in qualitative research?, Quality \& Quantity, 46. 
Przewoźna-Krzemińska, A.,2010. Rola ocen pracowniczych w pobudzaniu kreatywności zasobów ludzkich. Kreatywność i organizacje w zarządzaniu innowacjami. Wydawnictwo WZ PCz. Częstochowa.

Przewoźna-Krzemińska, A.,2015. A Personnel Audit as an Element of Employee Motivation and Commitment. Proceedings of the 5th International Conference on Management 2015. "Management, Leadership and Strategy for SME Competitiveness".ICM 2015, Godollo, Hungary.

Przewoźna-Krzemińska, A., 2017. Renumeration and Trainings as HR Audit Components Increasing the Employee Motivation and Commitment .Management, Organizations and Society. Agroinform Publishing House, Budapest.

Sapeta, T., 2004. Audyt personalny w kreowaniu przedsiębiorczości pracowników, Wydawnictwo Poltext, Warszawa.

Szałkowski, A.,2000. Wprowadzenie do zarządzania personelem, Wydawnictwo Akademii Ekonomicznej, Kraków.

http://prawo.sejm.gov.pl/isap.nsf/download.xsp.. Public Finance Act, Paragraph 1. 